\title{
Improving meatball quality using different varieties of rice bran as natural antioxidant
}

\author{
*Kartikawati, M. and Purnomo, H. \\ Department of Agriculture Product Technology, Faculty of Tourism, Ciputra University, Surabaya, East \\ Java, Indonesia
}

\author{
Article history: \\ Received: 20 September 2018 \\ Received in revised form: 29 \\ October 2018 \\ Accepted: 31 October 2018 \\ Available Online: 14 \\ November 2018 \\ Keywords: \\ Meat ball, \\ Rice bran, \\ Antioxidant, \\ Functional quality
}

DOI:

https://doi.org/10.26656/fr.2017.3(1).220

\begin{abstract}
Meatballs are very popular in every social class in many developing countries including Indonesia and are produced both under the cottage or commercial meat processing industries. Rice bran contains antioxidants and therefore the substitution of cassava starch (tapioca) in making meatball are expected to improve the functional quality of "bakso" into one of traditional healthy restructured meat product. Rice bran has antioxidant activity which different among varieties and agronomical environment. Therefore, the objective of this study was to determine the bioactive compounds such us antioxidant activity of crude extract of rice bran from Bramo, Serang and Menthik rice varieties, those were obtained from East Java, Indonesia and to study the efficacy of utilization the above rice bran to improve functional quality of meat ball. Results of the study showed that the best substitution preferred by panelists was the substitution of tapioca starch with $50 \%$ Serang rice bran with organoleptic scores of $4.98 ; 4.84 ; 4.93 ; 4.6 ; 4.5$ and 4.9 , respectively, for color, aroma, hardness, chewiness, taste, and flavor. This substitution treatment also increased $(p<0.05)$ the antioxidant activity from $16.75 \%$ to $35.78 \%$ and total phenol of meatballs from $37.82 \mathrm{mg} / 100 \mathrm{~g}$ to $90.81 \mathrm{mg} / 100 \mathrm{~g}$. The results also showed that substitution of tapioca starch with $50 \%$ Serang rice bran obviously improved the eating quality of the meatballs as a community healthy food.
\end{abstract}

\section{Introduction}

Meatballs are restructured meat products which can be produced from ground beef, pork, chicken or fish and beef meatballs being the most popular in Indonesia. This product is prepared by mixing finely ground beef with cassava starch (tapioca), cooking salt and sodium tripolyphosphate (STP) and the meatball batter are formed into marble of pingpong ball size or smaller/ bigger, and boiled until well cook (Romans et al., 1994; Purnomo and Rahardiyan, 2008). According to Fischer (1996), beef meatballs are made of 53\% lean beef, 17\% fat and starch, STP, salt, monosodium glutamate (MSG) $30 \%$ ice cubes. While Rahardiyan (2002) reported that Indonesian meatball or better known as "bakso" are prepared using finely ground beef mixed with cooking salt, starch and garlic.

Beef meatballs are very popular in every social class in Indonesia are being produced in cottage industries as well as by commercial meat processing manufactures (Purnomo and Rahardiyan, 2008). Since meatball is a popular meat product, it would be ideal to improve its nutritive value and functional quality such as enhancing its antioxidant content to produce a healthy food.

Antioxidants act as radical scavenger, can decrease oxidative stress, so it plays a vital role in prevention of various disease. The use of natural antioxidant in food is more preferable compared to the use of synthetic antioxidant for the consumers (Lobo et al., 2010). Therefore, substitution of cassava starch (low in antioxidant content) with rice bran as source of natural antioxidant, and it can be a viable option to develop meatball into one of traditional functional restructured meat product.

Rice bran is the cuticle between paddy husk and rice grain produced during rice milling and is mainly sold cheaply as animal feed (Kahlon, 2009). Rice bran is reported to contain fiber and also high in energy and protein and also contain zinc, iron, folic acid and other nutrients but no cholesterol (Rabbani and Ali, 2009). It also contains phytochemicals including phytosterols, vitamin B group and polyphenols, and polyphenols are commonly known as antioxidants (Rabbani and Ali, 2009). All these constituents contribute to the lowering blood serum cholesterol, have anti-cancer properties and 
protect the body from free-radical damage (Amarasinghe et al., 2009).

The antioxidant activity in rice bran different among rice varieties and agronomical environment $(\mathrm{Xu}$ and Godber, 2001; Nam et al., 2006; Sompong et al., 2011). Although antioxidant of rice bran has been extensively studied, the potential antioxidant of local rice bran is still lack. Therefore, the objectives of this study were to determine the bioactive compounds such as antioxidant activity of crude extract rice bran from several varieties of rice, namely Bramo, Serang and Menthik and to study the efficacy of the above rice bran to improve functional quality of meatball as a community healthy food.

\section{Materials and methods}

\subsection{Preparation of rice bran samples}

Rice varieties used in this study were local rice such as Bramo, Serang, and Menthik. All dry paddy samples were dehulled and milled to obtain mainly white rice and rice bran flour as by-product. The freshly milled rice bran samples were collected immediately from the milling in polyethylene plastic bags. Stabilization of rice bran was carried out according to methods as reported by Amarasinghe et al. (2009) and Bagchi et al. (2014) with slight modification. A total of $100 \mathrm{~g}$ of fresh fine powder rice bran was exposed to microwave heating for $2.5 \mathrm{mins}$ in polyethylene plastic bags and stored in refrigerator at $4^{\circ} \mathrm{C}$ until laboratory analysis.

\subsection{Preparation of Indonesian meatball}

The preparation of meatball followed the method of Rahardiyan (2002) with slight modification. The formula was as follows: finely ground shank beef $(1000 \mathrm{~g})$, ice cubes $(288 \mathrm{~g})$, cassava starch (144 g where in this study this starch was substituted with 50 (72 g) and 100\% (144 g) rice bran, and control or sample without substation of starch was made), cooking salt (24 g), fried garlic (16 g), fried red onion (16 g) and STP (4 g). These ingredients were mixed thoroughly using meat cutter to make the meatball batter and then it was formed into balls and subsequently boiled for 15 minutes. Well cook meatballs were cooled to ambient temperature, and then packed in nylon vacuum bag, vacuumed and stored at $4{ }^{\circ} \mathrm{C}$ before laboratory analysis was conducted.

\subsection{Experimental design}

This study was conducted in a two-stage laboratory experiment. Stage 1 of the experiment was conducted to study the antioxidant activity, anthocyanin content and total phenolic content from three different rice bran varieties and the second stage of the experiment was to study the effect of substitution of cassava starch with rice bran in meatball production having antioxidant activity, high phenolic content and acceptable for consumers. Experimental design of this study was randomized completely experimental design. All experiments were carried out with three replications of analysis and the data obtained will be processed by mathematical and statistical methods. Data were subjected using one-way analysis of variance (ANOVA) using the statistical analysis Microsoft Excel for Mac, significance at 5\% $(\mathrm{p}<0.05)$ (Gedrovica and Karklina, 2013). The means were separated by Tukey's honestly significant difference (HSD) to Realstat-2011 that was added to Microsoft Excel for Mac (Ott and Longnecker, 2001).

\subsection{DPPH radical scavenging assay}

Antioxidant activity test of crude extract of rice bran was determined by the free radical-scavenging 1,1diphenyl-2- picrylhydrazyn (Lee et al., 2006). The extraction of antioxidant compound was conducted by mixing $200 \mathrm{mg}$ sample with $5 \mathrm{~mL}$ of methanol and shaken for $1 \mathrm{hr}$. $5 \mathrm{~mL}$ supernatant extract was reacted with $1 \mathrm{~mL}$ DPPH $0.1 \mathrm{mM}$ working solution. The mixture was shaken and incubated in the dark condition at room temperature for 30 mins (Hatano et al., 1988; Yen and Chen, 1995). The absorbance was measured by UV-Vis spectrophotometer at $517 \mathrm{~nm}$. The inhibition was calculated using following formula:

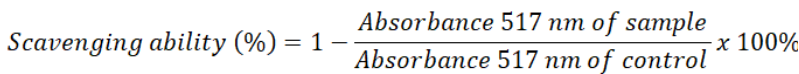

\subsection{Total phenolic content}

Total phenolic content of crude extract of rice bran was determined by spectrophotometric method using the Follin-Ciocalteu reagent (Singleton and Rossii, 1965). Rice bran was extracted by maceration with ethanol $60 \%$ for one night and repeated for three times. A total of one hundred microliters of the crude extract of rice bran solution $(5 \mathrm{mg} / \mathrm{mL})$ was mixed with $1.5 \mathrm{~mL}$ sodium carbonate solution $10 \%$ and then $3 \mathrm{~mL}$ of FollinCiocalteu $10 \%$ reagent was added. The final mixture was kept in the dark condition at ambient temperature for 2 hrs to complete the reaction. The absorbance was measured by spectrophotometer at $765 \mathrm{~nm}$. All measurements were determined triplicate and the data will be expressed as mg Gallic Acid Equivalent (GAE) per $100 \mathrm{~g}$ of crude extract of rice bran.

\subsection{Total anthocyanin content}

Determination of the total amount of anthocyanins was carried out using spectrophotometric method as reported by Markakis (1982) and Moko et al. (2014). A total of $100 \mathrm{~g}$ sample was macerated with $100 \mathrm{~mL}$ mixture of ethanol $95 \%$ and $\mathrm{HCl} 1.5 \mathrm{~N}(85: 15, \mathrm{v} / \mathrm{v})$ and stored at $4^{\circ} \mathrm{C}$ for overnight. The mixture was decanted 
and the pomace was washed repeatedly with acidic ethanol solvent and made up to volume $500 \mathrm{~mL}$. Anthocyanins were measured using spectrophotometer at wavelength $535 \mathrm{~nm}$ against a blank reagent. Cyanidin 3 glucoside chloride was used as standard pigment, and total anthocyanin content will be expressed as $\mathrm{mg}$ cyanidin 3 glucose equivalent per $100 \mathrm{~g}$ sample.

\subsection{Sensory evaluation}

Preference of the meatballs with rice bran was evaluated by thirty untrained panelists for each replication with hedonic test (Beinner et al., 2010). Each panelist was served with seven samples (without rice bran (0) as control, substitution with Bramo rice bran $50 \%$ (B50), substitution with Bramo rice 100\% (B100), substitution with Serang rice bran $50 \%$ (S50), substitution with Serang rice bran $100 \%$ (S100), substitution with Menthik rice bran 50\% (M50), substitution with Menthik rice bran $100 \%$ (M100)). Meatballs were offered to panelists for sensory evaluation using a 7-point hedonic scale to determine the panelists expression in the degree of liking or disliking for each kind of sample (Beinner et al., 2010) whereby the scale was described as 7 - like very much, 6 - like moderately, 5 - like slightly, 4 - neither like nor dislike, 3 - disliked slightly, 2- disliked moderately and 1 disliked very much. Seven coded samples were served and water was provided for rinsing the panelists mouth between taste the samples. The organoleptic parameters including color, aroma, hardness, chewiness, taste, and flavor. Panelists were asked to choose the best and the worst with comment for better understanding.

\section{Results and discussion}

3.1 Determination of antioxidant properties and phytochemical contents of rice bran from Jombang and Kediri

The overall results of the antioxidant properties and phytochemical contents of rice bran are shown in Table 1. The antioxidant activity was determined with DPPH free radical scavenging for each variety of rice bran and the average radical scavenging activity varied between Bramo, Serang and Menthik $(\mathrm{p} \leq 0.05)$ which were $15.25 \pm 0.07,25.37 \pm 0.07$, and $28.15 \pm 0.19 \%$, respectively. Phytochemical contents were studied from total anthocyanin content and total phenolic content. Total anthocyanin content $(\mathrm{p} \leq 0.05)$ was ranged from $2.23 \pm 0.07$ to $3.89 \pm 0.05 \mathrm{mg} / 100 \mathrm{~g}$ and total phenolic content was not significantly different $(\mathrm{P}>0.05)$ between varieties which ranged from $266.05 \pm 19.19$ to $286.72 \pm 1.37 \mathrm{mg} / 100 \mathrm{~g}$. From this study, Menthik rice bran was the best for the antioxidant activity, total anthocyanin content and total phenolic content. Saenkod et al. (2013) also proved different varieties of brown rice from China had different antioxidant activity and total phenolic compound. Hartati et al. (2015) also reported that a variety of rice influencing the antioxidant activity and phytochemical content and between IR-64, Sintanur, Rajalele, and Menthik. Menthik was observed as the best for total phenolic content and antioxidant activity. Furthermore, Huang and $\mathrm{Ng}$ (2012) and Hartati et al. (2015) also showed that higher total phenolic content of rice bran also give a higher antioxidant activity.

\subsection{Effect of substitution with rice bran in meatballs to antioxidant activity and total phenolic content}

Antioxidant activity and total phenolic content from meatball with rice bran substitution are shown in Table 2. Substitution cassava starch with rice bran was able to increase antioxidant activity and total phenolic contents of meatballs. Since meatball was added by fried garlic and fried red onion which contains antioxidant (Rohmawati et al., 2016), meatball without rice bran has also antioxidant activity $16,75 \%$ and total phenolic content $37.82 \mathrm{mg} / 100 \mathrm{~g}$. Wariyah and Riyanto (2018) reported that substitution ice with Aloe vera gel to chicken meatball increased antioxidant activity of meatball, but it is only from 5.51 (control) to $12.89 \%$ (60\% substitution). When substituted with rice bran (50\% to $100 \%$ from cassava starch), antioxidant activity was increased significantly $(\mathrm{P}<0.05)$ from 19.71 to $55.21 \%$ and total phenolic content from 84.06 to 100.76 $\mathrm{mg} / 100 \mathrm{~g}$. Antioxidant activity and total phenolic content increased significantly $(\mathrm{p} \leq 0.05)$ as the percentage of substitution with rice bran were increased. This indicated that substitution with rice bran can improve quality of meatballs, as functional and healthy food. Even Menthik rice bran had the best antioxidant activity, anthocyanin, and phenolic content when it was used in meatball production. While Serang rice bran had higher antioxidant activity and total phenolic content. Antioxidant capacity in foods after processing can be either positive or negative depended on antioxidant status (Min et al., 2014). It is assumed that antioxidant Menthik rice bran and phenolic content are more susceptible to heat treatment than Serang rice bran. Ko et al. (2003) and Min et al. (2014) also reported that the

Table 1. Antioxidant properties and phytochemical contents of Rice Bran from Jombang and Kediri

\begin{tabular}{cccc}
\hline Rice Varieties & DPPH $(\%)$ & Total Anthocyanin Content $(\mathrm{mg} / 100 \mathrm{~g})$ & Total Phenolic Content(mg/100g) \\
\hline Bramo & $15.25 \pm 0.07^{\mathrm{c}}$ & $2.90 \pm 0.01^{\mathrm{b}}$ & $266.05 \pm 19.19^{\mathrm{a}}$ \\
Serang & $25.37 \pm 0.07^{\mathrm{b}}$ & $2.23 \pm 0.07^{\mathrm{c}}$ & $276.92 \pm 1.00^{\mathrm{a}}$ \\
Menthik & $28.15 \pm 0.19^{\mathrm{a}}$ & $3.89 \pm 0.05^{\mathrm{a}}$ & $286.72 \pm 1.37^{\mathrm{a}}$ \\
\hline
\end{tabular}

Means \pm standard deviations with different alphabet superscripts within a column are significantly different at $\mathrm{p}<0.05$ 
total vitamin $\mathrm{E}$ homologue content in rice bran increased when exposed to heat treatment, but then decreased following longer heating times. Vitamin E was suggested strongly linked to insoluble cellular component and could be released by heating rice bran. Same with vitamin $\mathrm{E}$, total phenolic inbound fractions also increased with hydrothermal processes. Ferulic acid is known as the major phenolic compounds bound to the cell wall in grains. Heat treatment causes the instability of cell wall structure and binding properties, that made an increase in extractability of bound phenolic, that would increase antioxidant activity. However, if further heat treatment is applied, antioxidant activity and phenolic content will be decreased due to the degradation of antioxidant (Min et al., 2014).

Table 2. Antioxidant activity and total phenolic content from meatball with rice bran substitutions

\begin{tabular}{ccc}
\hline $\begin{array}{c}\text { Substitution of Rice } \\
\text { Bran }\end{array}$ & DPPH (\%) & $\begin{array}{c}\text { Total Phenolic } \\
\text { Content }(\mathrm{mg} / 100 \mathrm{~g})\end{array}$ \\
\hline 0 & $16.75 \pm 0.18^{\mathrm{g}}$ & $37.82 \pm 0.44^{\mathrm{f}}$ \\
B50 & $19.71 \pm 0.06^{\mathrm{f}}$ & $84.06 \pm 0.68^{\mathrm{e}}$ \\
B100 & $39.53 \pm 0.18^{\mathrm{c}}$ & $92.31 \pm 0.94^{\mathrm{c}}$ \\
S50 & $35.78 \pm 0.31^{\mathrm{d}}$ & $90.81 \pm 1.24^{\mathrm{cd}}$ \\
S100 & $55.21 \pm 0.36^{\mathrm{a}}$ & $100.76 \pm 0.99^{\mathrm{a}}$ \\
M50 & $30.49 \pm 0.07^{\mathrm{e}}$ & $89.56 \pm 0.06^{\mathrm{d}}$ \\
M100 & $42.77 \pm 0.31^{\mathrm{b}}$ & $95.31 \pm 0.68^{\mathrm{b}}$ \\
\hline
\end{tabular}

Means \pm standard deviations with different alphabet superscripts within a column are significantly different at $\mathrm{p}<0.05$

According to Kumar et al. (2015), one of the majority of natural antioxidants from plant origin is tocopherols besides flavonoid and phenolic acids. Antioxidant inhibits lipid oxidation by reacting to free radicals which is happened in the initiation phase, propagation phase or termination phase. Lipid and their derivatives are present in muscles. When meat ages, myoglobin is converted to metmyoglobin, which acts as a catalyst for lipid oxidation. When rate of lipid oxidation increases, deterioration of product color and flavor occurs. It is assumed that antioxidant components in rice bran were g-oryzanol and tocopherol (PestanaBauer et al., 2012). Gamma oryzanol has potential effect to stabilize free radical which is caused by organical radicals (Juliano et al., 2005). Tocopherol can act as donor or acceptor of chain breaking electron and to stabilize singlet oxygen scavenging (Shahidi, 1997).

\subsection{Effect of substitution with rice bran in meatballs to acceptance of consumer}

The acceptance test for rice bran meatball has been done by a 7-point hedonic scale (Table 3). Color acceptance was not significantly $(\mathrm{p} \geq 0.05)$ different between meatball without rice bran (control) and 50\% substitution of tapioca, but significantly $(\mathrm{p} \leq 0.05)$ higher to $100 \%$ substitution. Since rice bran is brown, substitution of rice bran made the meatball's color darker. Wanyo et al. (2009) reported that $\mathrm{L}^{*}$ value decreased and $a^{*}$ and $b^{*}$ value increased as the increase of rice bran substitution on rice flake, which means its color became darker. Meatball with $100 \%$ substitution with rice bran was too dark in its color and cause a decrease in the consumer likeness to the color of meatball.

Aroma of rice bran was different between each variety, some rice bran gave a pleasant sweet or nutty flavor that improve aroma of food, but other rice bran gave unpleasant odor (Hu et al., 2009; Gracia et al., 2012). The best aroma was performed by sample substituted with $50 \%$ of Menthik rice bran but not significantly $(\mathrm{p} \geq 0.05)$ different with other rice bran varieties and without substitution. However, substitution of 50 to $100 \%$ rice bran give significant differences in aroma $(\mathrm{p} \leq 0.05)$.

Increase of rice bran substitution have decreased the hardness, chewiness and likeness of meatball. Substitution with $50 \%$ rice bran was not significantly different with the one without substitution ( $p \geq 0.05$ ), but $100 \%$ substitution of tapioca with rice bran was significantly different $(p \leq 0.05)$. Panelists found that meatball with $100 \%$ substitution of rice bran was too hard. Substitution with $50 \%$ Bramo rice bran had a significantly lower score of taste than without substitution. Panelist noted that meatball samples substituted with Bramo rice bran had a strange taste. However, different with Bramo rice bran substituted samples, that the taste of meatballs substituted with $50 \%$ of Menthik rice bran and Serang rice bran were better than without substitution even it was not significantly

Table 3. Organoleptic result for meatballs with rice bran substitutions.

\begin{tabular}{ccccccc}
\hline Substitution of Rice Bran & Color & Aroma & Hardness & Chewiness & Taste & Flavor \\
\hline 0 & $5.26 \pm 0.22^{\mathrm{a}}$ & $4.92 \pm 0.12^{\mathrm{ab}}$ & $5.30 \pm 0.50^{\mathrm{a}}$ & $5.3 \pm 0.35^{\mathrm{a}}$ & $4.51 \pm 0.05^{\mathrm{a}}$ & $4.57 \pm 0.17^{\mathrm{a}}$ \\
B50 & $4.96 \pm 0.53^{\mathrm{a}}$ & $4.52 \pm 0.45^{\mathrm{abc}}$ & $4.44 \pm 0.69^{\mathrm{a}}$ & $4.63 \pm 0.66^{\mathrm{abc}}$ & $3.83 \pm 0.25^{\mathrm{b}}$ & $3.87 \pm 0.20^{\mathrm{ab}}$ \\
B100 & $4.03 \pm 0.12^{\mathrm{c}}$ & $3.94 \pm 0.20^{\mathrm{c}}$ & $3.18 \pm 0.15^{\mathrm{b}}$ & $3.07 \pm 0.03^{\mathrm{bc}}$ & $2.9 \pm 0.21^{\mathrm{c}}$ & $3.01 \pm 0.28^{\mathrm{c}}$ \\
S50 & $4.98 \pm 0.05^{\mathrm{a}}$ & $4.84 \pm 0.15^{\mathrm{ab}}$ & $4.90 \pm 0.18^{\mathrm{a}}$ & $4.93 \pm 0.22^{\mathrm{abc}}$ & $4.6 \pm 0.09^{\mathrm{a}}$ & $4.50 \pm 0.19^{\mathrm{a}}$ \\
S100 & $4.22 \pm 0.13^{\mathrm{bc}}$ & $4.14 \pm 0.40^{\mathrm{bc}}$ & $3.19 \pm 0.17^{\mathrm{b}}$ & $3.31 \pm 0.43^{\mathrm{abc}}$ & $3.27 \pm 0.24^{\mathrm{bc}}$ & $3.44 \pm 0.16^{\mathrm{bc}}$ \\
M50 & $4.92 \pm 0.45^{\mathrm{ab}}$ & $5.03 \pm 0.35^{\mathrm{a}}$ & $4.63 \pm 0.67^{\mathrm{a}}$ & $5.01 \pm 0.67^{\mathrm{ab}}$ & $4.53 \pm 0.35^{\mathrm{a}}$ & $4.27 \pm 0.37^{\mathrm{a}}$ \\
M100 & $4.31 \pm 0.25^{\mathrm{bc}}$ & $4.13 \pm 0.15^{\mathrm{bc}}$ & $2.97 \pm 0.20^{\mathrm{b}}$ & $2.92 \pm 0.18^{\mathrm{c}}$ & $2.8 \pm 0.31^{\mathrm{c}}$ & $2.96 \pm 0.49^{\mathrm{c}}$ \\
\hline
\end{tabular}

Means \pm standard deviations with different alphabet superscripts within a column are significantly different at $\mathrm{p}<0.05$ 
different $(\mathrm{p} \geq 0.05)$. Panelists who chose meatballs with $50 \%$ substitution of Menthik and Serang rice bran as the best samples, stated that the taste of these meatballs was the tastiest. Delahaye et al. (2004) also showed that enrichment $5 \%$ of rice bran to pizza dough was higher in likeness score than without rice bran. Therefore, rice bran in a certain amount could give a nice taste making them more attractive. Substitution with $100 \%$ rice bran was significantly $(\mathrm{p} \leq 0.05)$ decreased taste score, and make meatballs were not preferable to panelists.

Flavor is the integration of taste odors and oral somatosensory quality. Flavor seems to be important attribute of food that influence our motivation to consume (Prescott, 2015). Same with color, aroma, hardness, and chewiness, substitution with $50 \%$ rice bran was not significantly different with the samples without rice bran, but $100 \%$ rice bran substitution significantly decreased the flavor score of meatball. From all of the results, the best substitution was $50 \%$ substitution with Serang rice bran since it was not significantly different with highest score in organoleptic result $(\mathrm{p} \geq 0.05)$ but had better antioxidant activity which is significantly different from $50 \%$ substitution with Menthik rice bran $(\mathrm{p} \leq 0.05)$.

\section{Conclusion}

Substitution of tapioca with rice bran in the production of meatballs could increase the antioxidant activity and total phenolic content of meatballs. Although rice bran from Menthik rice variety had the highest antioxidant activity, anthocyanin, and phenolic contents, when used for meatball production, meatballs with substitution of starch with Serang rice bran had highest antioxidant activity and phenolic content. Results from this study showed that substitution of tapioca with $50 \%$ Serang rice bran was most appropriate to improve the functional quality of meatball as a healthy food.

\section{Conflict of Interests}

The authors declare that there is no conflict of interests regarding the publication of this paper.

\section{Acknowledgments}

The authors would like to express our sincere gratitude to the Research Internal Grant officers of Ciputra University for funding this study.

\section{References}

Amarasinghe, B.M.W.P.K., Kumarasiri, M.P.M. and Gangodavilage, N.C. (2009). Effect of Method of Stabilization on Aqueous Extraction of Rice Bran Oil. Food and Bioproducts Processing, 87(2), 108-
114. https://doi.org/10.1016/j.fbp.2008.08.002

Bagchi, T.B., Adak, T. and Chattopadhyay, K. (2014). Process Standardization for Rice Bran Stabilization and Its Nutritive Value. Journal of Crop and Weed, 10(2), 303-307.

Beinner, M.A., Soares, A.N.D., Barros, A.L.A. and Monteiro, M.A.M. (2010). Sensory evaluation of rice fortified with iron. Cienca e Tecnologia de Alimentos Campinas, 30(2), 516-519. https:// doi.org/10.1590/S0101-20612010000200034

Delahaye, E.P., Jimenez, P. and Perez, E. (2005). Effect of enrichment with high content dietary fiber stabilized rice bran flour on chemical and functional properties of storage frozen pizzas. Journal of Food Engineering, 68(1), 1-7. https://doi.org/10.1016/ j.jfoodeng.2004.05.048

Fischer, A. (1996). Classification and quality aspects of German processed meat. Indonesia: Brawijaya University.

Gedrovica, I. and Karklina, D. (2013). Sensory Evaluation of Meatballs with Jerusalem Artichoke (Helianthus tuberosus L.). International Journal of Social, Behavioral, Educational, Economic, Business and Industrial Engineering, 7(3), 752-754.

Gracia, M.C., Benassi, M.T. and Junior, M.S.S. (2012). Physicochemical and sensory profile of rice bran roasted in microwave. Cienca e Tecnologia de Alimentos Campinas, 32(4), 752-754. https:// doi.org/10.1590/S0101-20612012005000097

Hartati, S., Marsono, Y., Suparmo. and Santoso, U. (2015). Chemical Composition and Antioxidant Activity of Rice Bran Hydrophilic Extract of Selected Rice Variety. Agritech, 35(1), 35-42. https://doi.org/10.22146/agritech.9417

Hatano, T., Kagawa, H., Yasuhara, T. and Okuda, T. (1988). Two new flavonoids and other constituents in licorice root: their relative astringency and radical scavenging effects. Chemical and Pharmaceutical Bulletin, 36(6), 2090-2097. https://doi.org/10.1248/ cpb.36.2090

Hu, G., Huang, S., Cao, S. and Ma, Z. (2009). Effect of enrichment with hemicellulose from rice bran on chemical and functional properties of bread. Food Chemistry, 115, 839-842. https://doi.org/10.1016/ j.foodchem.2008.12.092

Huang, S.-H. and Ng, L.-T. (2012). Quantification of polyphenolic content and bioactive constituents of some commercial rice varieties in Taiwan. Journal of Food Composition and Analysis, 26(1-2), 122127. https://doi.org/10.1016/j.jfca.2012.03.009

Juliano, C., Cossu, M., Alamanni, M.C. and Piu, L. (2005). Antioxidant activity of gamma-oryzanol: 
Mechanism of action and its effect on oxidative stability of pharmaceutical oils. International Journal of Pharmaceutics, 229(1-2), 146-154. https://doi.org/10.1016/j.ijpharm.2005.05.018

Kahlon, T.S. (2009). Rice Bran: Production, Composition, Functionality and Food Applications, Physiological Benefits. In Cho, S.S. and Samuel, P. (Eds.). (2009). Fiber ingredients: food applications and health benefits, p. 305-322. USA: CRC Press.

Ko, S., Kim, C., Kim, C., Kim, H., Chung, S. and Lee, S. (2003). Changes of vitamin E content in rice bran with different heat treatment. European Journal of Lipid Science and Technology, 105(5), 225-228. https://doi.org/10.1002/ejlt.200390045

Kumar, Y., Yadav, D.N., Ahmad, T. and Narsaiah, K. (2015). Recent Trends in the use of natural antioxidants for meat and meat products. Comprehensive Reviews in Food Science and Food Safety, 14(6), 796-812. https://doi.org/10.1111/15414337.12156

Lee, D.J., Kim, K.H., Kang, J.H., Kim, J.B., Lee, Y.S. and Kim, H.W. (2006). Antioxidant and anticancer activities of methanolic extracts in grains of the Korea rice landraces. Korean Journal International Agriculture, 18, 264-269.

Lobo, V., Patil, A., Phatak, A. and Chandra, N. (2010). Free radicals, antioxidants and functional foods: Impact on human health. Pharmacognosy Reviews, 4 (8), 118-126. https://doi.org/10.4103/09737847.70902

Markakis, P. (Ed.). (1982). Anthocyanins as Food Colors. New York: Academic Press.

Min, B., McClung, A. and Chen, M.H. (2014). Effects of hydrothermal processes on antioxidant in brown, purple and red bran whole grain rice (Oryza sativa L.). Food Chemistry, 159, 106-115. https:// doi.org/10.1016/j.foodchem.2014.02.164

Moko, E.M., Purnomo, H., Kusnadi, J. and Ijong, F.G. (2014). Phytochemical Content and Antioxidant Properties of Colored Varieties of Rice Bran from Minahasa, North Sulawesi, Indonesia. International Food Research Journal, 21(3), 1053-1059.

Nam, S.H., Choi, S.P., Kang, M.Y., Kho, H.J., Kozukue, N. and Griedman, M. (2006). Antioxidative activities of bran extracts from twenty-one pigmented rice cultivars. Food Chemistry, 94(4), 613 -620 .

j.foodchem.2004.12.010

Ott, R.L. and Longnecker, M. (2001). An Introduction to Statistical Methods and Data Analysis. $5^{\text {th }}$ ed. Pacific Grove, CA: Duxbury Press.
Pestana-Bauer, V.R., Zambiazi, R.C., Mendonça, C.R., Beneito-Cambra, M. and Ramis-Ramos, G. (2012). $\gamma$ -Oryzanol and tocopherol contents in residues of rice bran oil refining. Food Chemistry, 134(3), 14791483.

https://doi.org/10.1016/

j.foodchem.2012.03.059

Prescott, J. (2015). Flavours: the pleasure principle. Flavour, 4(15), 1-3. https://doi.org/10.1186/20447248-4-15

Purnomo, H. and Rahardiyan, D. (2008). Review article: Indonesian traditional meatball. International Food Research Journal, 15(2), 101-108.

Rabbani, G.H. and Ali, M. (2009) New ideas and concepts rice bran: a nutrient-dense mill-waste for human nutrition. The Orion Medical Journal, 32(3), 694-701.

Rahardiyan, D. (2002). Bakso (Indonesian traditional meatballs) properties with rigor condition and frozen storage. USA: Louisiana State University, MSc. Thesis.

Rohmawati, S., Pangestuti, D.R. and Widajanti, L. (2016). Differences of Total Peroxide in Vegetable Oil with Addition of Red Onion and Garlic as Natural Antioxidant: Fried Food Seller in Tembalang District, Semarang City 2016. Jurnal Kesehatan Masyarakat, 5(1), 307-314.

Romans, J.R., Costello, W.J., Carlson, C.W., Greaser, M.L. and Jones, K.W. (1994). The Meat We Eat. $13^{\text {th }}$ ed. Danville: Interstate Publishers Inc.

Saenkod, C., Liu, Z., Huang, J. and Gong, Y. (2013). Anti-oxidative biochemical properties of extracts from some Chinese and Thai rice varieties. Academic Journals, 7(9), 300-305.

Shahidi, F. (1997). Natural Antioxidants: Chemistry, Health Effects, and Applications. United States of America: AOCS Press.

Singleton, V.L. and Rossi, J.A.Jr. (1965). Colorimetry of total phenolics with phosphomolybdicphosphotungstic acid reagents. American Journal Enology Viticulture, 16(3), 144-158.

Sompong, R., Siebenhandl-Ehn, S., Linsberger-Martin, G. and Berghofer, E. (2011). Physicochemical and antioxidative properties of red and black rice varieties from Thailand, China and Sri Lanka. Food Chemistry, 124(1), 132-140. https://doi.org/10.1016/ j.foodchem.2010.05.115

Wanyo, P., Chomnawang, C. and Siriamornpun, S. (2009). Substitution of wheat flour with rice flour and rice bran in flake products: effects on chemical, physical and antioxidant properties. World Applied Sciences Journal, 7(1), 49-56.

Wariyah, C. and Riyanto. (2018). Antioxidative Effect 
and the Acceptability of Chicken Meatball Added with Aloe vera Gel. Agritech, 38(2), 125-132. https:// doi.org/10.22146/agritech.31850

$\mathrm{Xu}, \mathrm{Z}$. and Godber, J.S. (2001). Antioxidant activities of major components of $\gamma$-oryzanol from rice bran using a linoleic acid model. Journal of the American Oil Chemists' Society, 78(6), 645-649. https:// doi.org/10.1007/s11746-001-0320-1

Yen, G.C. and Chen, H.Y. (1995). Antioxidant activity of various tea extracts in relation to their antimutagenicity. Journal of Agricultural and Food Chemistry, 43(1), 27-32. https://doi.org/10.1021/ jf00049a007 